\title{
Approach Safety
}

\author{
Peter Vittek \\ Laboratory of Aviation Safety and Security \\ Department of Air Transport, Faculty of Transportation Sciences, Czech Technical University in Prague \\ Horská 3, Praha 2, 128 03, Czech Republic \\ e-mail:vittek@fd.cvut.cz
}

\begin{abstract}
Safety and approach are two areas which are very important in aviation. Their mutual link is also one of contemporary very important challenges that aviation faces. This article deals with an overview of the current situation in this area.
\end{abstract}

Keywords-Aviation safety, approach, safety indicators

\section{INTRODUCTION}

Aviation safety is an area, to which is given increasing attention, despite the negative attitude of various stakeholders from aircraft operators to the supervising authorities. Current solutions, examining and assessing of aviation safety is provided by means of safety studies that are being developed to all changes introduced in the aviation sector.

At present, there is an effort to optimize the growth of aviation as one important transport segment. This should be achieved by allowing the introduction of IFR operations at uncontrolled aerodromes in uncontrolled airspace. Although these procedures are normally used in the world, it is a novelty in the Czech Republic, which must be tested first. [11]

\section{APPROACH}

Approach to landing is the final phase of the flight, when the aircraft is guided from the arrival route to a landing on the runway. It consists of four flight phases. The most important one is the final approach, which, together with landing, is the most dangerous phase of flight. This is shown in Figure 1.

The consequences of the hazard of this phase of the flight will vary based on the used approach system, which indicates a great influence on the safety. It is dependence, which should not be so serious due to actual setting of regulations.

There are several types of approach. Their current nomenclature is changed thanks to ICAO PBN manual 4th edition. Comparison of old and new nomenclature is in Table 1.

TABLE I. PBN NOMENCLATURE

\begin{tabular}{|c|c|}
\hline \multicolumn{2}{|c|}{ Approach } \\
\hline Old name & New name \\
\hline Precision approach & 3D approach \\
\hline $\begin{array}{c}\text { Approach with vertical } \\
\text { guidance }\end{array}$ & 3D approach \\
\hline Non-precision approach & 2D approach \\
\hline
\end{tabular}

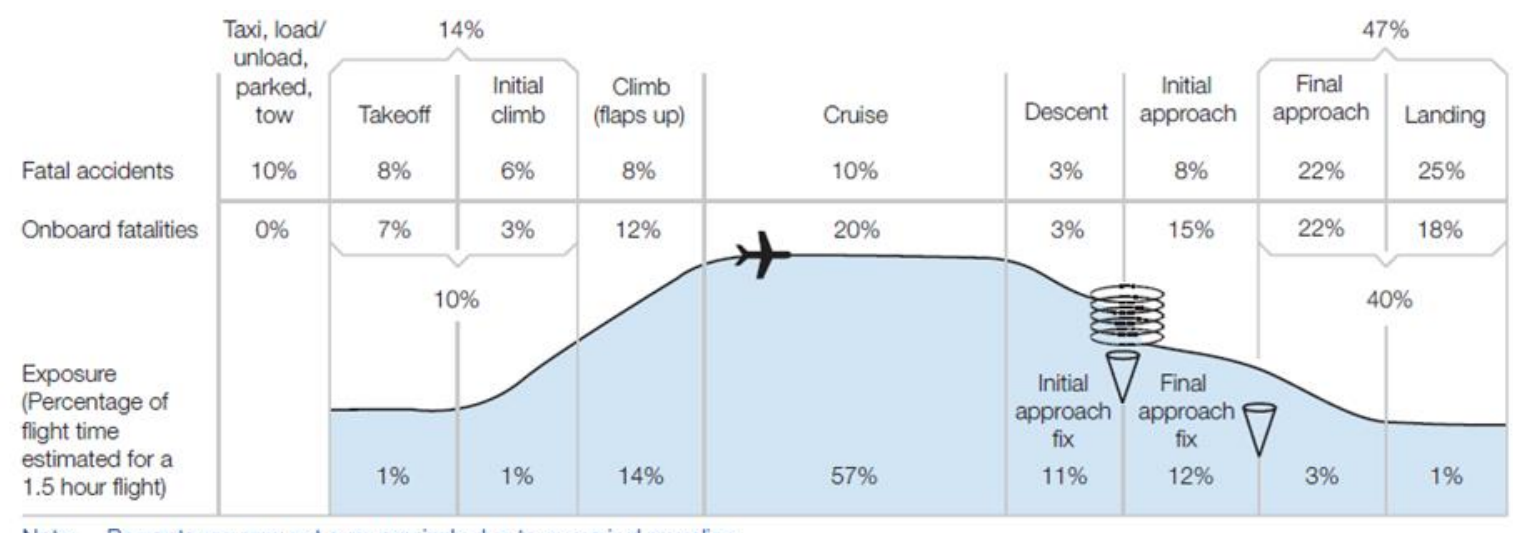

Note: Percentages may not sum precisely due to numerical rounding.

Figure 1. Percentage of fatal accidents and onboard fatalities [30] 
Using a simple view on this problematic, it would thus be possible to identify that the $3 \mathrm{D}$ approach must be safer than the 2D approach, but this statement is not necessarily true. [16], [25], [27]

\section{AVIATION SAFETY}

From the perspective of approach safety assessment has aviation safety adequate objectives to risk management - thus reducing the risk to ALARP (As Low As Reasonably Practicable). ALARP is defined in ICAO Doc. 9859 Safety Management Manual as the three areas of risk. It is shown in Figure 2.

\section{ALARP}

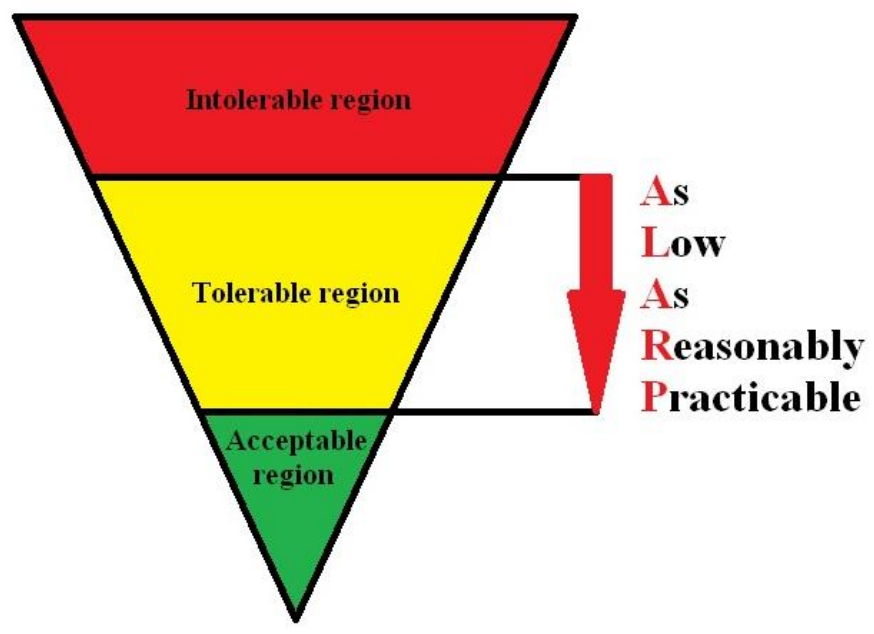

Figure 2. ALARP

More generally from the social perspective, this safety is dealt with acceptable level of safety (ALOS), which is required to define by the state in its State Safety Programme (SSP). The state should for all segments of aviation define measurable indicators and target levels that must be achieved. The main purpose of issuing SSP is reaching ALoS.

Achieving and maintaining ALoS can be problematic due to the system, which will ensure it. From the beginning, it is necessary to determine the reasonable values of ALoS, for which are mostly used safety indicators. When the safety indicators are nation widely determined, they must met two essential conditions. They must be look at from the availability point of view, respectively there must be enough data from the aviation stakeholders for their assessment, so that the indicator is conclusive. At the same time, the indicators should apply for various types of stakeholders.

In the case of an incorrect setting of an acceptable level of safety (ALoS), the aviation stakeholders could deviate from safety management to ALARP value and use the opposite system SAHARA (Set As High As Regulations Allow, Figure 3). Basically it is the same model of risk management, but the value of ALARP is moved to greater risks. This approach may not be detectable by anyone and neither the regulator may be able to detect it.

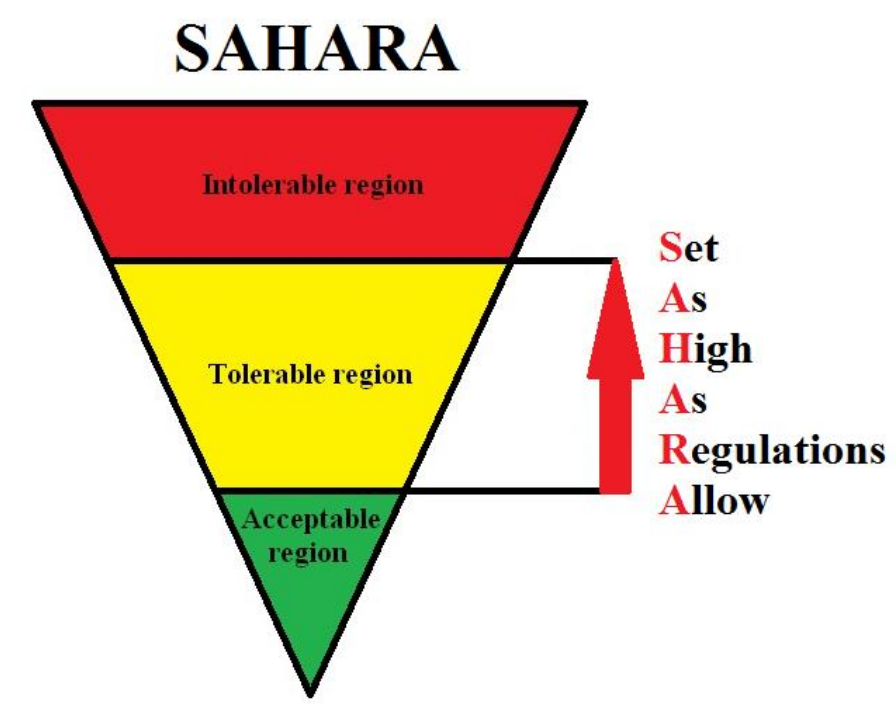

Figure 3. SAHARA

\section{A. Safety Study}

Given the need for maintaining safety it is required to create a safety study for every change that will value whether the future state will be acceptably safe. From the perspective of risk management, it appears to be most appropriate that the newly introduced change will maintain the level of safety, respectively it will increase it.

However, safety study is only a backing material for decision-making and it is in no way binding. This is defined by the fact that only in ideal condition there would be possible to create two safety studies by independent subjects with the same conclusion. In fact, the conclusions will undoubtedly vary and sometimes even quite dramatically.

Therefore, the essence of the safety study is not a final safety evaluation, but proposed safety requirements and safety recommendations. It is also possible to use the safety study as a basis for the creation of additional barriers that would increase safety. [15]

\section{IFR APPROACH TO UNCONTROLLED AERODROME}

As already mentioned, IFR operations at uncontrolled aerodromes are a common phenomenon in the world. In the Czech Republic there are such procedures till now unused, so it is necessary to ensure the level of safety during the transition from the current state without IFR operations at uncontrolled aerodromes to the new one.

The introduction of IFR operations at uncontrolled aerodromes must resolve several key areas [10] such as:

\section{1) Airspace class/type}

From the airspace point of view, there must be addressed airspace class selection, minimums setting or other additional rules. [1], [6], [17], [19]

\section{2) Approach type}

For small uncontrolled aerodrome, transformation from VFR to IFR traffic is very substantial benefit, largely thanks to allowing scheduling of flights at the aerodrome with a high 
probability of landing. Therefore, the operation will not be limited by the VMC. From this perspective, it is irrelevant for the aerodrome what type of approach will be implemented in this first implementation step, whether 2D or 3D. [7], [13], [21], [29]

\section{3) Approach system type}

The most appropriate approach system is the GNSS, because it means the lowest possible deployment costs. [2], [9], [14], [18], [24], [26]

\section{4) Requirements for aerodrome equipment}

Required aerodrome equipment is dependent on the approach system, regulations and on the requirements of the CAA. [21], [29], [11]

\section{5) ATS requirements}

At an uncontrolled aerodrome, where the IFR traffic will be introduced, it is necessary to provide ATS services as ATC or AFIS. [12], [16]

\section{6) Maintaining an acceptable level of safety}

The last major requirement is to maintain an acceptable level of safety in the implementation and after the introduction of a new type of operation. [3], [15], [22], [23], [25], [27], [28]

In the Czech Republic, all these areas are currently addressed by the working group led by the Ministry of Transport of the Czech Republic, which deals with pilot project of implementation of IFR operations at uncontrolled aerodromes at the airport in Hradec Kralove.

\section{CONCLUSION}

Safety assessment is crucial for aviation. Its use can be found in increasingly more changes that are approved mainly based on safety studies, since the regulations (standards and recommendations) cannot cover all the implementation cases.

Equally important is evaluating the current situation in order to have safety comparison for changes. For this evaluation is the best to use the safety indicators, which are structured queries into database (of classified events).

\section{ACKNOWLEDGMENT}

This paper was supported by the Grant Agency of the Czech Technical University in Prague, grant No. SGS14/212/OHK2/3T/16.

\section{REFERENCES}

[1] Červený, F. - Kraus, J.: Analysis and Design of Implementation of Class F Airspace in the Czech Republic. MAD - Magazine of Aviation Development. 2014, vol. 2, no. 9, p. 9-12. ISSN 1805-7578.

[2] Droppa, T. - Kraus, J.: Analysis for the Implementation of LPV Approaches in the Czech Republic. MAD - Magazine of Aviation Development. 2014, vol. 2, no. 10, p. 4-7. ISSN 1805-7578.

[3] Hajda, O. - Kraus, J.: Economic evaluation of safety improvements in aviation. Perner's Contacts. 2014, vol. 9, no. 2, p. 5-14. ISSN 1801$674 X$.

[4] Jeřábek, K. - Kraus, J.: Helicopter Approach to Offshore Objects. Naše More. 2015, vol. 62, no. 2, p. 74-77. ISSN 0469-6255.

[5] Kraus, J.: Free Route Airspace (FRA) in Europe. Perner's Contacts. 2011, vol. 6, no. 5, p. 129-135. ISSN 1801-674X.
[6] Kraus, J.: Implementation of Traffic Information Zone in Czech Republic. MAD - Magazine of Aviation Development. 2013, vol. 1, no. 3, p. 19-22. ISSN 1805-7578.

[7] Kraus, J.: Introduction of Cloud Break Procedures for Czech Republic based on GNSS SBAS. MAD - Magazine of Aviation Development. 2013, vol. 1, no. 1, art. no. 1, p. 3-6. ISSN 1805-7578.

[8] Kraus, J.: Necessary changes in airspace of states in FAB Central Europe (FABCE). Acta Avionica. 2012, vol. 14, no. 25, p. 135-138. ISSN 1335-9479.

[9] Kraus, J. - Capoušek, L.: Transformation of Helicopter PinS Procedures for Airplanes. MAD - Magazine of Aviation Development. 2013, vol. 1, no. 5, art. no. 1, p. 3-6. ISSN 1805-7578.

[10] Kraus, J. - Duša, T.: Obstacles in the Implementation and Publication of RNP Approaches at European Airports. Acta Avionica. 2012, vol. 14, no. 23, p. 69-73. ISSN 1335-9479.

[11] Kraus, J. - Jeřábek, K.: Introduction of IFR Approach to VFR Aerodrome. Acta Avionica. 2014, vol. 16, no. 29, p. 41-44. ISSN 13359479.

[12] Kraus, J. - Jeřábek, K.: Management of Airspace around Uncontroled Aerodromes. Perner's Contacts. 2013, vol. 8, no. 2, p. 79-87. ISSN 1801$674 \mathrm{X}$.

[13] Kraus, J. - Němec, V.: Analysis of Instrument Approaches to GA Aerodromes in the World. MAD - Magazine of Aviation Development. 2014, vol. 2, no. 8, art. no. 1, p. 4-10. ISSN 1805-7578.

[14] Kraus, J. - Ninger, J. - Jeřábek, K.: Implementation and Certification of LPV Approach and Options for VFR Aerodromes. MAD - Magazine of Aviation Development. 2013, vol. 1, no. 2, p. 3-6. ISSN 1805-7578.

[15] Kraus, J. - Ondrášková, J.: Analysis of Appropriate Methods for Assessment of Safety in Aviation. MAD - Magazine of Aviation Development. 2014, vol. 2, no. 11, p. 4-8. ISSN 1805-7578.

[16] Kraus, J. - Pleninger, S.: The Need to Increase Safety at Uncontrolled Aerodromes. Perner's Contacts. 2012, vol. 7, no. 4, p. 60-66. ISSN 1801$674 \mathrm{X}$.

[17] Volena, T. - Kraus, J.: Traffic Information Zone and its implementation in the Czech Republic. MAD - Magazine of Aviation Development. 2014, vol. 2, no. 12, p. 5-9. ISSN 1805-7578.

[18] Duša, T. - Kraus, J. - Duka, T.: GNSS Centre of Excellence and Implementation of GNSS Based Approach procedures. In International Conference on Air Transport 2013. Zilina: EDIS, 2013, p. 21-26. ISBN 978-80-554-0776-0.

[19] Kraus, J.: Analysis of Options and the proposal to Introduce the Class F Airspace in the Czech Republic. In InAir 2012. Zilina: EDIS, 2012, p. 57-60. ISBN 978-80-554-0574-2.

[20] Kraus, J.: Extending the Use of GNSS in Aviation - Pilots Training. In Proceedings of the 11th European Transport Congress. Praha: České vysoké učení technické v Praze, Fakulta dopravní, 2013, p. 148-151. ISBN 978-80-01-05321-8.

[21] Kraus, J.: Possible Use of VFR Aerodromes as a Backup in Emergency Situations. In Mladá Veda 2012 - Veda a krízové situácie. Žilina: Fakulta špeciálneho inžinierstva Žilinskej univerzity v Žiline, 2012, p. 166-173. ISBN 978-80-554-0575-9.

[22] Kraus, J.: Safety Study and a New Type of Approach. In ZBORNÍK PRÍSPEVKOV Z III. KONFERENCIE DOKTORANDOV. Košice: Technická univerzita v Košiciach, 2014, art. no. 22, ISBN 978-80-5531687-1.

[23] Kraus, J. - Duša, T.: Increasing Safety at Uncontrolled Aerodromes in the Czech Republic - Introducing IFR Approach Procedures. In New Trend in Aviation Development. Košice: Faculty of Aeronautics Technical University Kosice, 2012, p. 1-5. ISBN 978-80-553-1083-1.

[24] Kraus, J. - Jeřábek, K.: Identifikace nebezpečí v přiblíženích pomocí procesních modelů. In AIR TRANSPORT 2014. Košice: Technická Univerzita, 2014, s. 66-68. ISBN 978-80-553-1867-7.

[25] Kraus, J. - Jeřábek, K.: The Possibility of Evaluating the Level of Approach Safety Given by the Regulations. In New Trends in Civil Aviation 2013. Žilina: Faculty of Opearation and Economics of Transport and Communications, University of Žilina, 2013, p. 44-47. ISBN 978-80-7204-843-4. 
[26] Kraus, J. - Ninger, J.: Alternative Certification of LPV Approaches at small aerodromes in the Czech Republic. In New Trends in Aviation Development 2014. Košice: Technická univerzita v Košiciach, Letecká fakulta, 2014, ISBN 978-80-553-1650-5.

[27] Kraus, J. - Pleninger, S.: Safety Culture vs. Strictness of Regulations. In New Trends in Civil Aviation 2014. Brno: Akademické nakladatelství CERM, 2014, p. 79-81. ISBN 978-80-7204-891-5.

[28] Kraus, J. - Plos, V.: Využití bezpečnostních indikátorů pro předcházení krizovým situacím. In Bezpečnost, spolehlivost a rizika 2014. Liberec: Technická univerzita v Liberci, 2014, ISBN 978-80-7494-110-8.
[29] Kraus, J. - Soporský, T. - Jeřábek, K.: Analysis of Czech Aerodromes in Terms of the Introduction of an Instrument Approach. In Increasing Safety and Quality in Civil and Military Air Transport. Žilina: Žilinská univerzita v Žilině Fakulta prevádzky a ekonomiky dopravy a spojov, 2013, p. 59-62. ISBN 978-80-554-0665-7.

[30] Boeing. Statistical Summary of Commercial Jet Airplane Accidents Worldwide Operations 1959-2013. 2013. [online]. [cit. 13.6.2015]. Available at: <http://www.boeing.com/resources/boeingdotcom/ company/about_bca/pdf/statsum.pdf> 